UDK 336.74(497.5)

339.923:061.1EU

Pregledni rad

Primljeno 12. kolovoza 2021.

\title{
Proces zamjene hrvatske kune eurom i očekivani utjecaj na gospodarska kretanja
}

VESNA CVITANOVIĆ

Sveučilište VERN', Zagreb

PETRA ŠIRANOVIĆ

Hrvatska narodna banka

\section{SAŽETAK}

Zadatak rada je istražiti tijek operacionalizacije procesa zamjene hrvatske kune eurom i utvrditi realne mogućnosti Republike Hrvatske za ispunjavanje četiri obvezna Kriterija nominalne konvergencije. Cilj je rada usmjeren na potvrđivanje hipoteze da će uvođenje eura donijeti pozitivne promjene životnog standarda hrvatskih građana, kvalitetnu platformu za uspješnije poslovanje gospodarskih subjekata i pozitivan trend ukupnih makroekonomskih pokazatelja. Korištenjem sekundarnih izvora podataka, javno dostupnih službenih publikacija i analizom internetskih izvora te primjenjujući metode komparacije, sinteze i indukcije, došlo se je do najvažnijih rezultata istraživanja: za Hrvatsku postoji realna mogućnost ostvarenja sva četiri Kriterija nominalne konvergencije: stabilnosti cijena, održivosti javnih financija, stabilnosti tečaja i konvergencije dugoročnih kamatnih stopa i da 2023. godine uđe u europodručje. Porast životnog standarda građana, blagi rast cijena, uklanjanje valutnih rizika, smanjenje troškova zaduživanja, poticanje međunarodne razmjene, povećanje stranih ulaganja te brži gospodarski rast i razvoj prednosti su koje će Hrvatskoj donijeti zamjena hrvatske kune eurom.

Ključne riječi: euro, Europska unija, europodručje, HNB, gospodarstvo 


\section{Uvod}

Republika Hrvatska postala je 1. srpnja 2013. godine punopravna članica Europske unije (EU). U cilju ostvarivanja dublje europske integracije, definirana su dva strateška nacionalna cilja: pristupanje europodručju i ulazak u Schengenski prostor. U svibnju 2018. godine, donošenjem Strategije za uvođenje eura kao službene valute u Hrvatskoj, pokrenut je proces ulaska u europodručje. Dana 10. srpnja 2020., hrvatska je kuna priključena Europskom tečajnom mehanizmu (ERM II), pa su time izvršene sve potrebne političke predradnje. Zadatak rada je sagledati realnost ispunjavanja četiri obvezna Kriterija nominalne konvergencije i istražiti tijek operativnih aktivnosti procesa zamjene hrvatske kune eurom. Cilj rada usmjeren je na potvrđivanje hipoteze da uvođenje eura ima višestruki utjecaj na promjene životnog standarda hrvatskih građana, poslovanje gospodarskih subjekata i trend ukupnih makroekonomskih pokazatelja zemlje. U uvodnom dijelu rada prikazani su zadatak i cilj rada, a u drugom poglavlju opisana je primijenjena metodologija korištena u radu. U trećem poglavlju koji nosi naziv „Diskusija“ obrađen je povijesni tijek stvaranja Europske unije, uvođenja eura kao jedinstvene europske valute i ulaska Hrvatske u europodručje. U četvrtom poglavlju pod nazivom „Rezultati istraživanja“ utvrđuje se mogućnost Hrvatske da ostvari zadana četiri Kriterija nominalne konvergencije kao preduvjeta ulaska u europodručje. Također, utjecaj uvođenja eura na rast cijena i druge makroekonomske pokazatelje analiziran je u četiri odabrane države te na kraju, tijek operacionalizacije zamjene kune eurom te utjecaj uvođenja eura za građane i gospodarske subjekte. $\mathrm{Na} \mathrm{kraju} \mathrm{rada,} \mathrm{u} \mathrm{Zaključku,} \mathrm{sumirana} \mathrm{su} \mathrm{zapažanja,} \mathrm{činjenice} \mathrm{i} \mathrm{rezultati} \mathrm{istraživanja} \mathrm{s} \mathrm{relevantnim}$ porukama i ekonomskim očekivanjima.

\section{Metodologija}

U radu je korištena raspoloživa literatura, a posebna pažnja usmjerena je na relevantne nacionalne dokumente, kao i znanstvene radove te rezultate istraživanja domaćih i stranih institucija. Prilikom internetskog pretraživanja korišteni su ključni pojmovi poput: euro, Europska monetarna unija, Europska središnja banka, Kriteriji nominalne konvergencije, HNB, zamjena kune eurom, BDP, javni dug, državni proračun, stopa inflacije i drugi.

U radu su analizirane stope inflacije i drugi makroekonomski pokazatelji u četiri odabrane zemlje: Njemačka je odabrana kao jedna od najrazvijenijih zemalja Europe, zemlja koja predstavlja treće najveće gospodarstvo svijeta (iza Amerike i Japana), koja ima najdugovječniju i najveću stabilnost tečaja i stabilnost cijena, i zemlja koja je najveći hrvatski vanjskotrgovinski partner. Austrija je odabrana kao zemlja koja Hrvatskoj može biti nit vodilja, koja nema visoko sofisticiranu proizvodnju, kojoj turizam, kao i Hrvatskoj, predstavlja stratešku gospodarsku granu, a koja je od ulaska u EMU do danas udvostručila BDP i BDP po glavi stanovnika te uz stabilnost cijena ostvaruje kontinuirani ekonomski rast. Francuska je odabrana kao zemlja koja ostvaruje oko petinu BDP-a zemalja europodručja i zemlja čije je gospodarstvo po veličini peto u svijetu. Slovenija je odabrana kao prva zemlja tranzicije koja je postala članicom europodručja.

U radu su korištene metoda deskripcije, metoda komparacije, metoda sinteze i induktivna metoda koje su omogućile uočavanje, otkrivanje i izučavanje znanstvene istine, radi formuliranja jedinstvenih zaključaka. 


\section{Diskusija}

EU predstavlja jedinstvenu gospodarsku i političku uniju od 27 europskih zemalja koje zajedno pokrivaju velik dio kontinenta (Europska unija, 2021, prema Širanović, 2021). Radi učinkovitije i poticajnije međunarodne gospodarske suradnje, u Rimu, 1958. godine nastala je Europska ekonomska zajednica (EEZ) koju je činilo šest zemalja Europske zajednice za ugljen i čelik, i to: Belgija, Njemačka, Francuska, Italija, Luksemburg i Nizozemska. Zemlje članice EEZ-a vezale su tečajeve svojih nacionalnih valuta za vrijednost američkog dolara. Početak europske monetarne integracije datira iz 1969. godine kada je na Summitu u Haagu donesen Barreov plan kojim je uspostavljen sustav kratkoročne monetarne potpore za članice EEZ-a radi rješavanja nastalih problema s platnim bilancama. (ESB, ESSB i Eurosustav, prema Širanović 2021). Godine 1979. kreiran je Europski monetarni sustav (EMS), prema kojemu su države članice EEZ-a trebale držati tečajeve svojih nacionalnih valuta prema košarici valuta EEZ-a unutar dogovorenih granica. Iako su sve valute bile ravnopravne, ubrzo se pokazalo da njemačka marka ima najveću stabilnost tečaja i stabilnost cijena, odnosno nisku stopu inflacije. U prosincu 1991. godine, predstavnici 12 država (šest članica EEZ-a, Danska, Grčka, Irska, Portugal, Španjolska i Ujedinjeno Kraljevstvo), u nizozemskom gradu Maastrichtu, potpisali su ugovor kojim je postavljena platforma za unaprjeđenje gospodarske suradnja među europskim državama i omogućeno uvođenje jedinstvene europske valute - eura (Frank i Bernanke, 2001). Ugovor je stupio na snagu 1. studenog 1993. godine, i toga dana, službeno su osnovane EU i Europska središnja banka (ESB) koja je započela djelovati u Frankfurtu 1. lipnja 1998. godine radi osiguranja stabilnosti cijena i vrijednost eura. Dana 1. siječnja 1999. godine euro je kao obračunska jedinica prihvaćen u jedanaest zemalja EU-a, i to u: Austriji, Belgiji, Finskoj, Francuskoj, Irskoj, Italiji, Luksemburgu, Nizozemskoj, Njemačkoj, Portugalu i Španjolskoj (Frank i Bernanke, 2001). Od 2002. godine, euro se kao gotovinsko sredstvo plaćanja koristi i predstavlja jedinstvenu valutu za dvanaest zemalja EU-a, jer se navedenim zemljama priključila i Grčka. Ovime je obuhvaćeno jedinstveno monetarno tržište od čak 300 milijuna stanovnika, a u promet je pušteno 15 milijardi novčanica i 60 milijardi kovanica eura. Nakon toga, EU-u je pristupilo još 16 država, a Ujedinjeno Kraljevstvo je 31. siječnja 2020. izašlo iz EU-a tako da EU danas čini 27 država članica. Jedinstvenu europsku valutu, euro, koristi oko 340 milijuna građana u 19 zemalja EU-a, a središnja banka za zemlje europodručja je Europska središnja banka.

Uvođenje eura omogućilo je članicama europodručja sljedeće prednosti: lakše provođenje međusobne trgovinske razmjene, zajednički nastup na međunarodnom tržištu, lakše provođenje investicijskih ulaganja te povećanje broja radnih mjesta. Od 2002. godine do danas, u europodručje priključilo se još sedam država, i to: Slovenija (2007. godine), Cipar i Malta (2008. godine), Slovačka (2009. godine), Estonija (2011. godine), Latvija (2014. godine) i Litva (2015. godine). Zemlje EU-a koje još nisu ušle u EMU su: Bugarska, Hrvatska, Češka, Mađarska, Poljska, Rumunjska i Švedska, s time da su Bugarska i Hrvatska u srpnju 2020. godine primljene u Europski tečajni mehanizam. Danska je jedina država EU-a koja je dogovorila izuzeće od eura i nema obvezu uvesti ga kao zakonsko sredstvo plaćanja.

\subsection{Proces uvođenja eura u Republiku Hrvatsku}

Europska monetarna unija (EMU) kao jedinstveno monetarno tržište EU-a usmjerena je, između ostalog, uklanjanju prekomjernih kolebljivosti u deviznim tečajevima država članica i smanjenju transakcijskih troškova te stvaranju optimalnog valutnog područja. 
Financijska integracija Hrvatske s europodručjem proizlazi iz činjenice da je od 2013. godine Hrvatska punopravni član EU-a čime je određen obvezni ulazak Hrvatske u Europsku monetarnu uniju. Hrvatska je usmjerena na države EU-a i članice europodručja, što potvrđuju sljedeći makroekonomski pokazatelji iz 2018. godine: u zemlje EU-a odlazi 68 \% hrvatskog izvoza (14 \% u Italiju, $13 \%$ u Njemačku i $11 \%$ u Sloveniju); više od 78 \% uvoza u Hrvatsku, čine proizvodi iz država članica EU-a, od čega je 15 \% iz Njemačke, 13 \% iz Italije i 11 \% iz Slovenije (Europa EU, 2021).

Pored toga, „financijske institucije država europodručja vlasnice su čak 75 \% imovine hrvatskog bankarskog sustava; 54 \% kreditnih zaduženja imaju valutnu klauzulu u eurima; u posljednjih osam godina prosječno $71 \%$ štednje stanovništva je u eurima; noćenja gostiju iz zemalja europodručja čine $61 \%$ inozemnih gostiju, a i najveći udio inozemnih izravnih ulaganja u Hrvatsku dolazi iz država europodručja“ (Vlada Republike Hrvatske, 2021).

U javnosti se ističe da će uvođenjem eura doći do gubitka monetarnog suvereniteta, potpunog gubitka samostalne monetarne i tečajne politike te da će nestajanjem nacionalne valute nestati važan simbol suvereniteta i nacionalnog identiteta Republike Hrvatske. Rezultati četvrtog istraživanja javnog mnijenja o uvođenju eura koje je provedeno u 2021. godini, koje je HNB objavila polovinom ožujka 2021., pokazali su da se udio građana koji podržavaju uvođenje eura povećao u odnosu na prethodni val istraživanja s $41 \%$ na $45 \%$. Međutim, i dalje se uvođenju eura protivi $19 \%$ građana, a $26 \%$ njih je uvjetno protiv, odnosno uvjetno za uvođenje eura. Građani najviše strahuju od povećanja cijena, pada standarda i kupovne moći (HNB 2021).

U srpnju 2020. godine, Hrvatska je primljena u ERM II, u tzv. „predvorje europodručja“, gdje će ostati do trenutka ispunjenja monetarnih i fiskalnih Kriterija nominalne konvergencije koji su definirani Ugovorom iz Maastrichta. Tom prilikom, utvrđen je središnji paritet između kune i eura od 7,53450 koji će se pratiti dok je Hrvatska u ERM-u II, a šest mjeseci prije datuma uvođenja eura bit će poznat fiksni paritet prema kojem će se vršiti konverzija.

U ERM-u II države ostaju najmanje dvije godine, a vezano uz to postoje različita iskustva država. Tako su primjerice, Slovenija, Cipar i Malta u ERM-u II provele tri godine, što je najkraće razdoblje, a Litva je primjer države koja je u tom statusu provela više od deset godina.

Tijek procesa uvođenja eura u Republiku Hrvatsku prikazan je na Slici 1.

Hrvatska mora izvršiti četiri Kriterija nominalne konvergencije, a to su: stabilnost cijena, održivost javnih financija, stabilnost tečaja i dugoročnih kamatnih stopa (Funda i sur., 2007, prema Širanović, 2021).

Europska komisija podnosi Vijeću EU-a izvještaj o konvergenciji kojim potvrđuje da su ostvareni zadani Kriteriji, a Vijeće EU-a u narednih šest mjeseci donosi odluku o ulasku Hrvatske u europodručje i odluku o fiksnom tečaju prema kojem će se vršiti zamjena kune u euro.

Nakon toga slijede aktivnosti kojima se definira vrijeme dvojnog iskazivanja cijena, načini plaćanja i proces postupka zamjene hrvatske kune u euro. Prva dva tjedna po uvođenju eura, građani će moći plaćati i kunama i eurima, a nakon toga, euro će postati jedino zakonsko sredstvo plaćanja. Dvojno iskazivanje cijena bit će na snazi 30 dana od datuma kada Vijeće EU-a bude donijelo odluku o uvođenju eura u Hrvatsku pa do proteka 12 mjeseci od datuma uvođenja eura.

Zamjenu kuna u eure obavljat će banke, FINA i Hrvatska pošta, tako da se samo u prvih šest mjeseci ne obračunava naknada. Nakon godinu dana, zamjenu kuna i eure obavljat će samo HNB i to bez naknade. 
Slika 1. Tijek procesa uvođenja eura u Republiku Hrvatsku
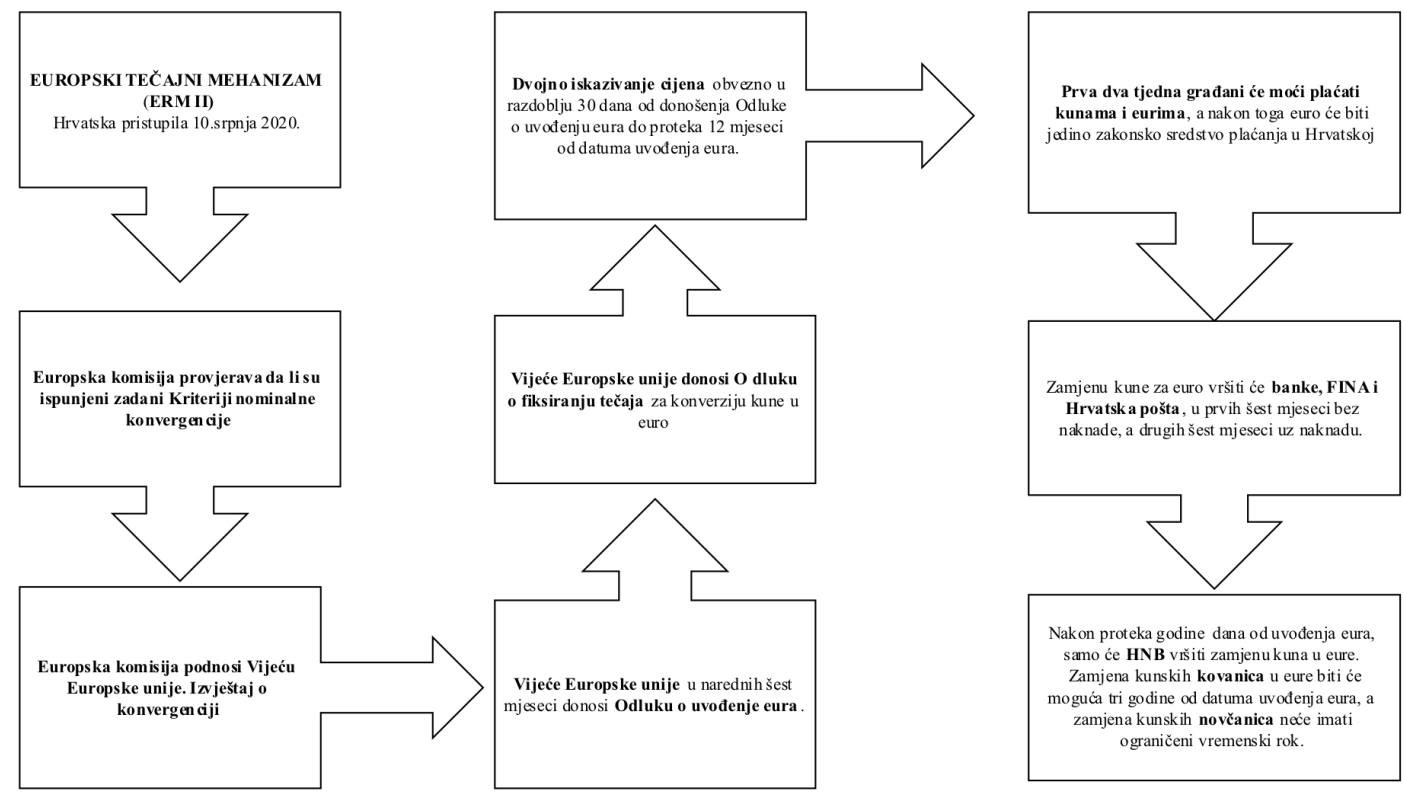

Izvor: autorski rad, prilagođeno, preuzeto s: https:/euro.hnb.hr/documents/2070751/2104255/

Nacionalni-plan-zamjene-hrvatske-kune-eurom_prosinac-2020.pdf/6bcd2d43-5ef8-1a8d-

00d1-86b9a71c696f (28.7.2021.)

Kunske kovanice HNB će primati tri godine od datuma uvođenja eura, a za zamjenu kunskih novčanica neće biti vremenskog ograničenja (Vlada RH i HNB, 2020).

\section{Rezultati istraživanja}

Ispunjavanje zadanih Kriterija nominalne konvergencije potvrđuje da država članica može doprinijeti nastavku makroekonomske stabilnosti i jačanju ugleda Europske monetarne unije.

\subsection{Analiza mogućnosti ostvarivanja Kriterija nominalne konvergencije}

Trend kretanja makroekonomskih pokazatelja Hrvatske od 2002. do 2019. godine vidljiv je u Tablici 1. Pokazatelji potvrđuju da je utjecaj Svjetske financijske krize ostavio dugoročne negativne posljedice na hrvatsko gospodarstvo pa je u razdoblju 2009. - 2014. godine pad bruto društvenog proizvoda (BDP) iznosio 11,8 \%, što je u narednim godinama bilo teško nadoknaditi. Od zadnjeg kvartala 2014. do 2019. godine, hrvatsko gospodarstvo bilježilo je pozitivna gospodarska kretanja: kontinuirani rast BDP-a, rast BDP-a per capita, a u razdoblju 2017.-2019. godine i kontinuirano smanjenje udjela javnog duga u BDP-u, kontinuirano smanjenje deficita platne bilance te suficit državnog proračuna. ${ }^{1}$ 
Tablica 1. Makroekonomski pokazatelji Hrvatske 2002. - 2019. godine

\begin{tabular}{c|l|c|c|c|c|c|c} 
R.B. & Makroekonomski pokazatelji & $\mathbf{2 0 0 2 .}$ & $\mathbf{2 0 0 4 .}$ & $\mathbf{2 0 0 7 .}$ & $\mathbf{2 0 0 9 .}$ & $\mathbf{2 0 1 3 .}$ & $\mathbf{2 0 1 9 .}$ \\
\hline 1. & BDP (u mlrd \$) & 26,8 & 41,6 & 60,1 & 62,6 & 58.2 & 60,8 \\
\hline 2. & BDP po glavi stanovnika (u \$) & 6.233 & 9.661 & 13.937 & 14.541 & 13.674 & 14.944 \\
\hline 3. & Izvoz robe (u mlrd \$) & 3,97 & 6,6 & 10,5 & 9,2 & 11,9 & 14,4 \\
\hline 4. & Uvoz robe (u mlrd \$) & 9,8 & 15,2 & 23,7 & 19,6 & 20,6 & 25,9 \\
\hline 5. & $\begin{array}{l}\text { Vanjskotrgovinska bilanca } \\
\text { (u mlrd \$) (3-4) }\end{array}$ & $-5,8$ & $-8,6$ & $-13,2$ & $-10,4$ & $-8,7$ & $-11,5$ \\
\hline 6. & $\begin{array}{l}\text { Vrijednost izvoza roba i usluga } \\
\text { (u mlrd \$) }\end{array}$ & 9,7 & 15,3 & 22,8 & 20,4 & 23,5 & 31,6 \\
\hline 7. & $\begin{array}{l}\text { Vrijednost uvoza roba i usluga } \\
\text { (u mlrd \$) }\end{array}$ & 12,2 & 18,9 & 27,8 & 24,0 & 24,6 & 31,7 \\
\hline 8. & Platna bilanca (5-6) & $-2,5$ & $-3,6$ & $-5,0$ & $-3,6$ & $-1,1$ & $-0,1$ \\
\hline 9. & Godišnja stopa inflacije (\%) & 1,7 & 2,1 & 2,9 & 2,4 & 2,2 & 0,8
\end{tabular}

Izvor: rad autora, korišteni podaci The World Bank, preuzeto s: https://databank.worldbank.org/ reports.aspx?source=world-development-indicators $(23.7 .2021$.

Izravni utjecaj na pozitivna gospodarska kretanja imao je turizam kao strateška gospodarska grana koji je u 2019. godini ostvario prihod od 10,5 milijardi eura, što je činilo 19,5 \% BDP-a Hrvatske (HTZ, prema HNB 2020). Pozitivna makroekonomska kretanja ilustriraju i podaci o godišnjoj stopi inflacije koji potvrđuju stabilnost cijena.

\subsubsection{Kriterij stabilnosti cijena}

Stabilnost cijena kao kriterij podrazumijeva da stopa inflacije ne smije biti veća od 1,5 postotnih poena prosječne stope inflacije tri zemlje EU-a koje bilježe najnižu inflaciju, odnosno imaju najniži indeks potrošačkih cijena u godini koja prethodi ulasku države kandidatkinje u EMU. Održavanje niske inflacije ključno je za ostvarenje bržeg gospodarskog rasta i uspješno sudjelovanje države članice unutar područja EMU-a. Državama s visokom stopom inflacije bila bi smanjena konkurentnost u odnosu na druge članice pa ih se i prije sudjelovanja u zajedničkoj monetarnoj politici, potiče na održavanje nižih stopa inflacije.

U EU-u inflacija se mjeri harmoniziranim indeksom potrošačkih cijena (HIPC) koji osigurava mjerenje inflacije na kompatibilnoj osnovi, uvažavajući različitost nacionalnih ekonomija. Iz grafičkog prikaza 1. može se vidjeti da je u lipnju 2019. godine stopa inflacije u Hrvatskoj bila među najnižima u EU-u. 


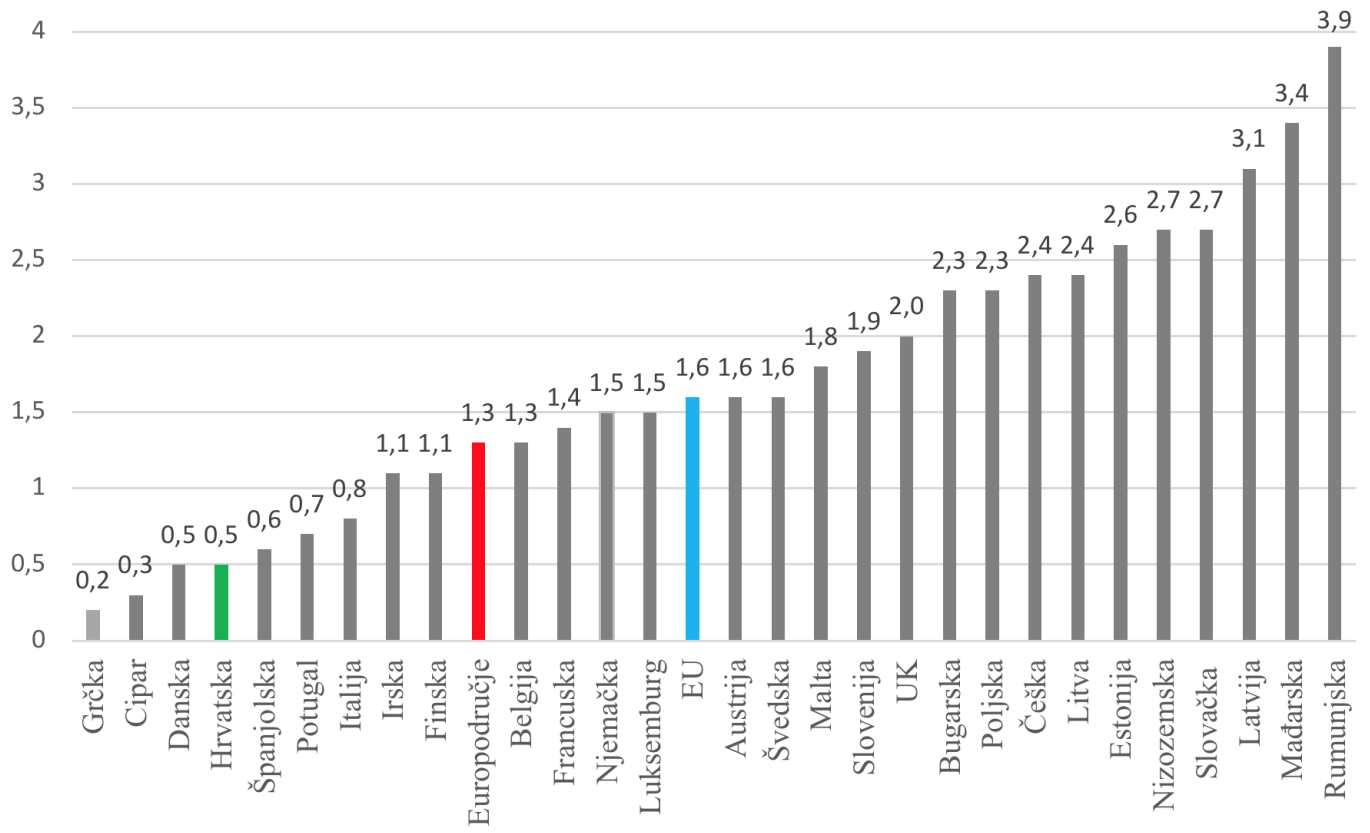

Izvor: autorski rad, prilagođeno od Eurostat news release euroindicators, preuzeto s: https:// ec.europa.eu/eurostat/documents/portlet_file_entry/2995521/2-17072019-AP-EN.pdf/ e507c971-54f9-4c0f-96d6-d619a8a912aa (27.7.2021.)

U razdoblju travanj 2019.- ožujak 2020. tri države članice EMU-a s najnižom stopom inflacije bile su: Portugal $(0,2 \%)$, Cipar $(0,4 \%)$ i Italija $(0,4 \%)$ pa je njihov aritmetički prosjek stope inflacije iznosio $0,33 \%$. Kada se doda 1,5 postotnih poena, dobiva se referentna vrijednost od 1,8 \%. (ECB, 2021). U ožujku 2020. prosječna dvanaestomjesečna stopa inflacije u Hrvatskoj iznosila je $0,9 \%$, što je značajno manje u odnosu na izračunatu referentnu stopu inflacije, pa se može zaključiti da Hrvatska ostvaruje prvi kriterij nominalne konvergencije - stabilnost cijena.

\subsubsection{Kriterij održivosti javnih financija}

Kriterij održivosti javnih financija odnosi se na visinu proračunskog deficita prethodne financijske godine koji mora biti manji od 3 \% BDP-a i na učešće javnog duga u BDP-u koje mora biti manje od $60 \%$. Ako bi ova vrijednost bila viša, državu članicu će se obvezati da u narednim godinama treba ostvariti tendenciju kontinuiranog smanjivanja kako bi se približila zadanoj referentnoj vrijednosti učešća javnog duga u BDP-u. (Vlada Republike Hrvatske, Hrvatska narodna banka, 2018.). Udio proračunskog deficita/suficita u BDP-u Hrvatske u razdoblju 2010. - 2019. može se vidjeti iz grafičkog prikaza 2. 
Graf 2. Udio proračunskog deficita/suficita u BDP-u Hrvatske 2010. - 2019.

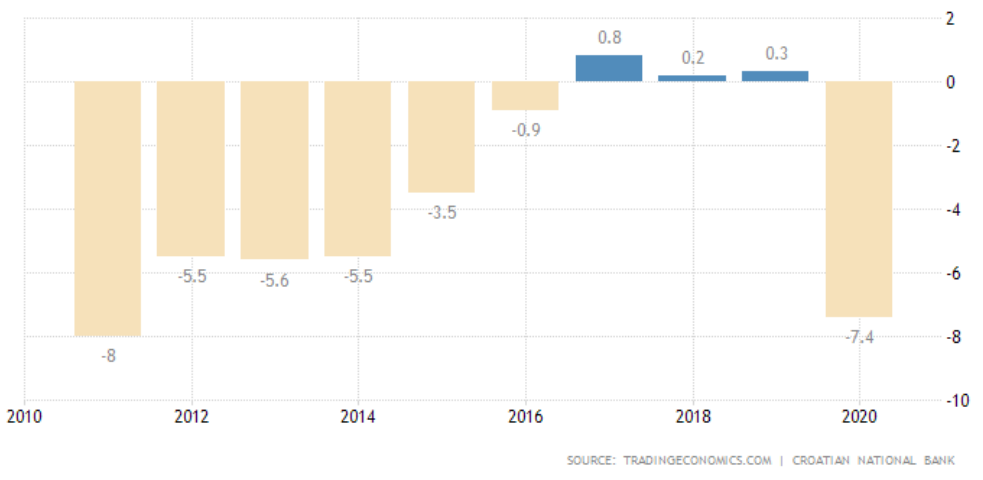

Izvor: Trading Economics, preuzeto s: https://tradingeconomics.com/croatia/government-budget (28.7.2021.)

Godine 2017. prekinut je kontinuitet proračunskog deficita, koji je bio posljedica utjecaja Svjetske financijske krize na hrvatsko gospodarstvo u razdoblju 2009. - 2014. godine, da bi u razdoblju od 2017. - 2019. godine, državni proračun Republike Hrvatske bio u suficitu kao što se može vidjeti u gornjem grafičkom prikazu. ${ }^{2}$

Kretanje udjela javnog duga u BDP-u Hrvatske u razdoblju 2010. - 2019. vidljivo je u grafičkom prikazu 3.

Graf 3. Udio javnog duga u BDP-u Republike Hrvatske u razdoblju 2010. - 2019.

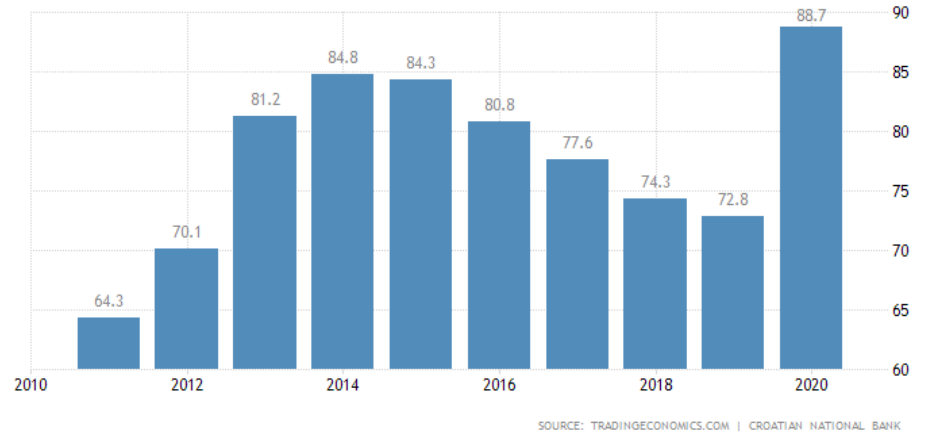

Izvor: Trading economic, preuzeto s: https://tradingeconomics.com/croatia/government-debt-to-gdp (27.7.2021.)

2 Hrvatska je 2020. ostvarila 27,4 milijarde kuna proračunskog deficita, što je 7,4 \% BDP-a (DZS, 2021). Smanjenje BDP-a u odnosu na 2019. godinu bilo je $8 \%$, što je veći pad nego krizne 2009. u odnosu na 2008. kada je BDP smanjen za 7,3\%. U 2020. godini smanjeni su proračunski prihodi i doprinosi za 24,8 milijarde kn, a uz to došlo je do povećanja javnih rashoda zbog mjera koje je Vlada poduzimala radi očuvanja radnih mjesta i zdravlja građana.

Poslovna očekivanja za 2021. i naredne godine predviđaju rast prihoda od turizma i ostalih gospodarskih grana i time smanjenje proračunskog deficita ispod ciljanih $3 \%$, a opravdanost ovih predviđanja potvrđuju podaci Hrvatske turističke zajednice (HTZ) i sustava eVisitor obrađeni na dan 3. kolovoza 2021. godine. Tijekom srpnja 2021. godine zabilježen je veći ukupan turistički promet (strani i domaći turisti) za $51 \%$, a broj noćenja povećan je za 37 u odnosu na srpanj 2020. godine (HTZ, 2021). 
Godine 2014. udio javnog duga u BDP-u Republike Hrvatske iznosio je $84,8 \%$ da bi već sljedeće, 2015. godine bio smanjen na $84,3 \%$. U 2016. godini zabilježeno je daljnje smanjenje na $80,8 \%$, a u 2017. godini na 77,6 \%. Pozitivni trend nastavljen je i 2018., a u 2019. udio javnog duga u BDP-u iznosio je 72,8 \%, pa se može zaključiti da će i drugi Kriterij nominalne konvergencije - Održivost javnih financija, biti ostvariv. ${ }^{3}$

\subsubsection{Kriterij stabilnosti tečaja}

Kriterij stabilnosti tečaja podrazumijeva da država kandidatkinja za ulazak u EMU mora imati stabilan devizni tečaj prema euru, minimalno dvije godine prije ulaska u EMU, odnosno da nominalni tečaj nacionalne valute prema standardnom rasponu može odstupati \pm 15 postotnih poena. Ulaskom Republike Hrvatske u europodručje, tečajna politika HNB-a neće se trebati mijenjati i moći će se nastaviti politika fluktuirajućeg tečaja kakva je bila u proteklom desetogodišnjem razdoblju kada je iznosila maksimalnih $2 \%$.

Kretanje tečaja eura i kune u desetogodišnjem razdoblju vidljiv je iz grafičkog prikaza 4.

Graf 4. Kretanje tečaja eura i kune u razdoblju 2009. - 2019.

\section{Kretanje tečaja EUR/HRK}

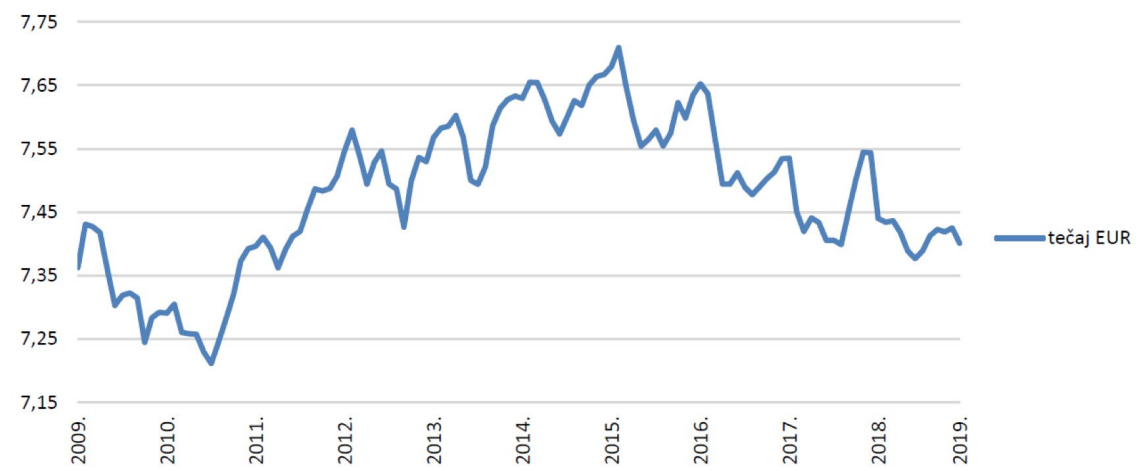

Izvor: Erstebank, preuzeto s: https://www.erstebank.hr/hr/gradjanstvo/krediti/informacije-ovalutnoj-klauzuli-i-kretanju-tecaja-eura (29.7.2021.)

U 2018. i 2019. godini, fluktuacija tečaja bila je vrlo mala i kretala se između 7,3571 do 7,4868 te je prosječan tečaj iznosio 7,42195 i kao takav je bio stabilan. Većina zemalja koja je ulazila u europodručje konvertirala je nacionalnu valutu u euro prema utvrđenom središnjem paritetu prilikom ulaska u EMR-II, pa je za očekivati da će tečaj 7,53450 biti primijenjen prilikom zamjene kune za euro.

Može se zaključiti da će i ovaj treći Kriterij nominalne konvergencije biti realno ostvariv.

3 Pozitivni trend kretanja udjela javnog duga u BDP-u prekinut je 2020. godine što je dovelo do potrebe zaduživanja države na domaćem i stranom financijskom tržištu. Javni dug 2020. godine bio je 329,7 milijardi kuna što je 88,7 \% vrijednosti BDP-a. U samo godinu danu došlo je do alarmantnog povećanja javnog duga za 12,6 \%. Za pretpostaviti je kako smanjenje udjela javnog duga u BDP-u Hrvatske neće biti jednostavno ostvariti u kratkom razdoblju i približiti se ciljanom od $60 \%$. Europska komisija, svjesna objektivnosti nastalih promijenjenih gospodarskih uvjeta, potvrdila je da će u naredne dvije godine, odstupiti od proračunskih pravila i članicama EU-a omogućiti fleksibilnost u borbi s pandemijom bez prijetnje da će se zbog prekomjernog manjka provoditi pokretanje procedura i eventualnih sankcija. Hrvatska će trebati svake godine smanjivati udio javnog duga u BDP-u za jednu dvadesetinu razlike između tekuće razine udjela javnog duga u BDP-u $(88,7$ \%) i ciljanog od $60 \%$ što znači da smanjenje treba biti 1,435\% godišnje. Hrvatska planira smanjivati udio javnog duga po godišnjoj stopi od 3,3 \%, što je dvostruko više od zadanog. (Vlada Republike Hrvatske, Hrvatska narodna banka, 2020). 


\subsubsection{Kriterij dugoročnih kamatnih stopa}

Kriterij dugoročnih kamatnih stopa analizira kamatne stope dugoročnih državnih obveznica i usporedivih vrijednosnih papira i zahtijeva da nominalna dugoročna kamatna stopa zemlje kandidatkinje za ulazak u europodručje u prethodnoj godini ne smije biti viša od dva postotna poena prema utvrđenoj kamatnoj stopi u tri zemlje članice koje imaju najvišu stabilnost cijena, odnosno najnižu inflaciju.

Graf 5. Dugoročne kamatne stope Republike Hrvatske u razdoblju svibanj 2019. - svibanj 2020.

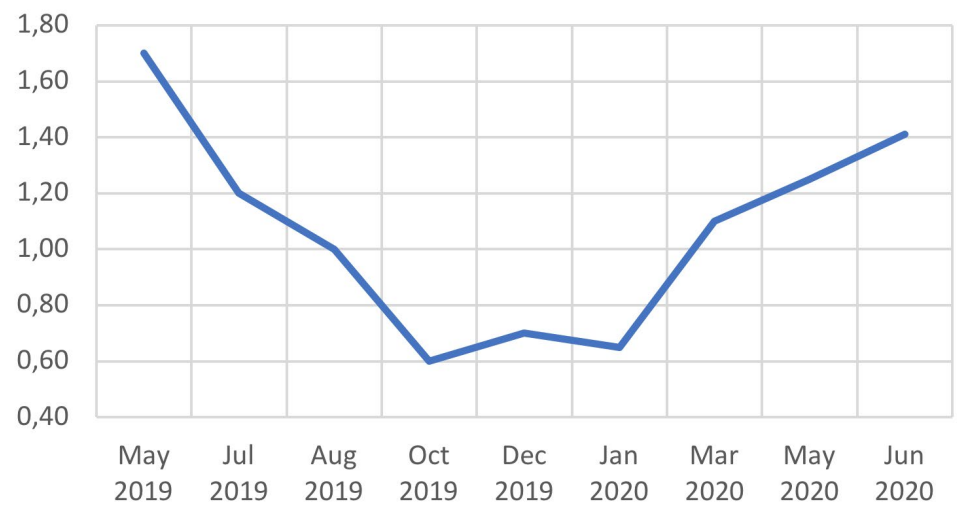

Izvor: prilagođen autorski rad, prema Šarganović, preuzeto s: https://www.ceps.edu.ba/Files/DIT/ Godina\%206\%20Broj\%201/19.pdf?ver=1, (29.7.2021.)

U 2019. godini, visina dugoročnih kamatnih stopa u Republici Hrvatskoj kretala se od 1,8 \% na niže, a u listopadu 2019. iznosila je najnižih 0,6\% .

Prema Izvješću o konvergenciji Europske centralne banke (ECB), iz lipnja 2020., tijekom referentnog razdoblja (travanj 2019. do ožujak 2020. godine), tri zemlje s najnižom stopom inflacije imale su sljedeće dugoročne kamatne stope: Portugal 0,5 \%, Cipar 0,8 \% i Italija 1,6 \% pa je prosječna kamatna stopa iznosila 0,9\%. Kada se dodaju dva postotna boda, dobiva se referentna vrijednost od 2,9\%. (ECB, 2021). Prema tome, može se zaključiti da Hrvatska ima niže dugoročne kamatne stope pa time ispunjava i ovaj četvrti zadani Kriterij iz Maastrichta. ${ }^{4}$

\subsection{Promjene nastale uvođenjem eura u odabranim zemljama}

Istraživanja potvrđuju da je u zemljama koje su uvodile euro kao nacionalnu valutu, postojao strah da će se značajno narušiti stabilnost cijena te da će uvođenje eura pokrenuti inflatornu spiralu. Međutim, pokazalo se da do toga nije došlo, ali da su znatno manju inflaciju imale one zemlje koje su određeno vrijeme imale istaknute cijene u trgovinama u obje valute. Također, uvođenje eura obilježilo je ekonomski napredak svake države članice europodručja, a posebno integracija i razvoj financijskog tržišta. Stanje je bilo poljuljano u godinama Svjetske financijske krize pa su od 2008. godine države morale voditi zahtjevne ekonomske borbe.

„Na temelju iskustava drugih članica EU-a koje su već provele konverziju nacionalnih valuta u euro, može se očekivati kako će učinak konverzije kune u euro na povećanje ukupne inflacije potrošačkih cijena u Hrvatskoj biti blag. Procjenjuje se da će učinak konverzije unutar Republike Hrvatske iznositi oko 0,20 postotnih bodova u odnosu na 
povećanje indeksa potrošačkih cijena, tj. u prosjeku 0,37 postotnih bodova u segmentu povećanja harmoniziranog indeksa potrošačkih cijena u periodu od pola godine prije i poslije konverzije“ (HNB, 2021).

\subsubsection{Njemačka}

Uvođenje eura 2002. godine izvršeno je tako da je njemačka marka zamijenjena eurom po tečaju: 1 $\mathrm{EUR}=1,95583$ DEM. Još i danas može se izvršiti zamjena maraka u eure s obzirom na to da procjene govore kako još uvijek postoji cca 12,46 milijardi DEM (6,37 milijardi eura) koju građani nisu pretvorili u eure (Direktno, 2019, prema Širanović, 2021). Danas svaki peti Nijemac posjeduje dionice, a u 1995. godini imao ih je svaki deseti državljanin. Procjenjuje se da je uvođenje eura dodatno potaknulo interes običnih ljudi za aktivno sudjelovanje na tržištu kapitala i izravno uključivanje u poslovne i ekonomske sadržaje (Welteke, 2001 prema Širanović, 2021). Svi makroekonomski pokazatelji Njemačke govore o snazi njemačkog gospodarstva, kontinuiranom suficitu vanjskotrgovinske bilance, kontroliranoj inflaciji te rastu BDP-a i BDP-a po glavi stanovnika. U ljeto 2007. u Americi je počela kriza, uzrokovana drugorazrednim, slabo osiguranim kreditima koja je ubrzo poprimila razmjere recentne globalne financijske krize (Reinhart, Rogoff, 2009). Posljedice ove krize pogodile su njemačko bankarstvo i automobilsku industriju, što se odrazilo na pad makroekonomskih pokazatelja ukupnog nacionalnog gospodarstva.

Tablica 2. Makroekonomski pokazatelji Njemačke 2002. - 2019. godine

\begin{tabular}{r|l|c|c|c|c|c|c} 
R.B. & Makroekonomski pokazatelji & $\mathbf{2 0 0 2 .}$ & $\mathbf{2 0 0 4 .}$ & $\mathbf{2 0 0 7 .}$ & $\mathbf{2 0 0 9 .}$ & $\mathbf{2 0 1 3 .}$ & $\mathbf{2 0 1 9 .}$ \\
\hline 1. & BDP (u mlrd \$) & $2.068,6$ & $2.809,2$ & $3.421,2$ & $3.397,8$ & $3.732,71$ & $3.861,1$ \\
\hline 2. & BDP po glavi stanovnika (u \$) & $25.077,7$ & $34.044,1$ & $41.587,2$ & $41.485,9$ & $46.285,8$ & $46.467,5$ \\
\hline 3. & Izvoz robe (u mlrd \$) & 578,7 & 853,2 & $1.270,7$ & $1.074,6$ & $1.423,0$ & $1.460,9$ \\
\hline 4. & Uvoz robe (u mlrd \$) & 444,5 & 663,6 & 994.2 & 817,2 & $1.152,4$ & $1.218,4$ \\
\hline 5. & $\begin{array}{l}\text { Vanjskotrgovinska bilanca } \\
\text { (u mlrd \$) (3-4) }\end{array}$ & 134,2 & 189,6 & 276,5 & 197,4 & 270,6 & 242,5 \\
\hline 6. & $\begin{array}{l}\text { Vrijednost izvoza roba i usluga } \\
\text { (u mlrd \$) }\end{array}$ & 674,2 & $1.003,33$ & $1.482,2$ & $1.295,2$ & $1.695,4$ & $1.810,6$ \\
\hline 7. & $\begin{array}{l}\text { Vrijednost uvoza roba i usluga } \\
\text { (u mlrd \$) }\end{array}$ & 586,3 & 857,2 & $1.250,5$ & 1.125 .0 & $1.480,4$ & $1.586,8$ \\
\hline 8. & Platna bilanca (6-7) & 87,9 & 146,1 & 231,7 & 170,2 & 215,0 & 223,8 \\
\hline 9. & Godišnja stopa inflacije (\%) & 1,4 & 1,7 & 2,3 & 0,3 & 1,5 & 1,4
\end{tabular}

Izvor: rad autora, korišteni podaci The World Bank, preuzeto s: https://databank.worldbank.org/ reports.aspx?source=world-development-indicators (22.7.2021.) 
Iz Tablice 2. vidljivo je da je u godini uvođenja eura (2002.), stopa inflacije u Njemačkoj iznosila 1,4 \%. Sve do Svjetske financijske krize, godišnja stopa inflacije bila je ispod $2 \%$, da bi u 2007. godini porasla na $2,3 \%$. Od 2009. godine do danas, stopa inflacije je ispod $2 \%$ godišnje što govori o stabilnosti cijena. Godine 2019. zabilježena je stopa inflacije od 1,4 \% što je gotovo jednako kao i u godini kada je Njemačka uvela euro.

\subsubsection{Austrija}

Ulaskom u europodručje, Austrija nije zabilježila značajna povećanja cijena na malo. „Rezultati istraživanja pokazuju (Deutsche Bundesbank, 2004. i ESB, 2003, prema Širanović, 2021) da je izrazitiji rast cijena zbog konverzije zabilježen kod manjeg dijela proizvoda, pretežno uslužnog sektora kao što su, usluge u restoranima i kafićima, usluge smještaja, frizerske usluge, različiti popravci, kemijsko čišćenje, rekreacijske i sportske usluge." (Pufnik, 2017, prema Širanović, 2021). Austrija je 2002. godine uvela euro kao nacionalnu valutu, a konverzija austrijskog šilinga u euro provedena je $\mathrm{u}$ omjeru 1 EUR = 13,7603 AST (ECB - Eurosustav, 2021).

Tablica 3. Makroekonomski pokazatelji Austrije 2002. - 2019. godine

\begin{tabular}{c|l|c|c|c|c|c|c} 
R.B. & Makroekonomski pokazatelji & $\mathbf{2 0 0 2 .}$ & $\mathbf{2 0 0 4 .}$ & $\mathbf{2 0 0 7 .}$ & $\mathbf{2 0 0 9 .}$ & $\mathbf{2 0 1 3 .}$ & $\mathbf{2 0 1 9 .}$ \\
\hline 1. & BDP (u mlrd \$) & 213,4 & 300,9 & 388,7 & 400,2 & 430,1 & 445,1 \\
\hline 2. & BDP po glavi stanovnika (u \$) & 26.402 & 36.822 & 46.856 & 47.963 & 50.717 & 50.122 \\
\hline 3. & Izvoz robe (u mlrd \$) & - & - & 156,8 & 131,8 & 164,3 & 170,8 \\
\hline 4. & Uvoz robe (u mlrd \$) & - & - & 151,5 & 132,5 & 165,6 & 167,5 \\
\hline 5. & $\begin{array}{l}\text { Vanjskotrgovinska bilanca } \\
\text { (u mlrd \$) (3-4) }\end{array}$ & - & - & 5,3 & $-0,7$ & $-1,3$ & 3,3 \\
\hline 6. & $\begin{array}{l}\text { Vrijednost izvoza roba i usluga } \\
\text { (u mlrd \$) }\end{array}$ & 96,7 & 141,0 & 204,3 & 180,9 & 229,8 & 247,4 \\
\hline 7. & $\begin{array}{l}\text { Vrijednost uvoza roba i usluga } \\
\text { (u mlrd \$) }\end{array}$ & 88,8 & 132,2 & 187,2 & 167,5 & 217,7 & 232,3 \\
\hline 8. & Platna bilanca (6-7) & 7,9 & 8,8 & 17,1 & 13,4 & 12,1 & 15,1 \\
\hline 9. & Godišnja stopa inflacije (\%) & 1,8 & 2,1 & 2,2 & 0,5 & 2,0 & 1,5
\end{tabular}

Izvor: rad autora, korišteni podaci The World Bank, preuzeto s: https://databank.worldbank.org/ reports.aspx?source=world-development-indicators $(22.7 .2021$.)

Godine 2004. stopa inflacije iznosila je 2,06 \%. Godinu 2008. obilježila je relativno visoka inflacija od 3,22 \%, dok je 2009. godine stopa inflacije iznosila blagih 0,51 \%. Godine 2019. godišnja stopa inflacije iznosila je 1,53 \% (Macrotrends, 2021, prema Širanović, 2021). Makroekonomski pokazatelji potvrđuju da je Austrija od ulaska u EMU do 2019. godine udvostručila BDP i da je BDP po glavi stanovnika gotovo dvostruko veći. Suficit vanjskotrgovinske bilance i platne bilance te niska godišnja stopa inflacije upućuju na stabilnu makroekonomsku politiku i kontinuirani ekonomski rast Austrije. 


\subsubsection{Francuska}

Francuska je 2002. godine uvela euro kao nacionalnu valutu, a konverzija se odvijala prema tečaju 1 EUR $=6,55957$ FRF. Uvođenjem eura, zbog smanjenja nesigurnosti i rizika, Francuska se više usmjerila na trgovinu sa zemljama EMU-a pa je zabilježeno smanjenje trgovine sa zemljama koje nisu članice europodručja. Prilikom konverzije francuskog franka u euro znatniji porast cijena na malo zabilježile su sljedeće grupe proizvoda: „čišćenje, popravak i iznajmljivanje odjeće, popravak audiovizualne, fotografske i informatičke opreme, usluge u restoranima, kafićima, frizerskim salonima i centrima za uljepšavanje“ (Pufnik, 2017, prema Širanović, 2021). Trend kretanja makroekonomskih pokazatelja vidljiv je u Tablici 4.

Tablica 4. Makroekonomski pokazatelji Francuske 2002. - 2019. godine

\begin{tabular}{r|l|c|c|c|c|c|c} 
R.B. & Makroekonomski pokazatelji & $\mathbf{2 0 0 2 .}$ & $\mathbf{2 0 0 4 .}$ & $\mathbf{2 0 0 7 .}$ & $\mathbf{2 0 0 9 .}$ & $\mathbf{2 0 1 3 .}$ & $\mathbf{2 0 1 9 .}$ \\
\hline 1. & BDP (u mlrd \$) & $1.494,3$ & $2.115,7$ & $2.657,2$ & $2.690,2$ & $2.811,1$ & $2.715,5$ \\
\hline 2. & BDP po glavi stanovnika (u \$) & 24.177 & 33.741 & 41.508 & 41.575 & 42.593 & 40.380 \\
\hline 3. & Izvoz robe (u mlrd \$) & 305,7 & 416,7 & 544,3 & 471,0 & 582,4 & 597,1 \\
\hline 4. & Uvoz robe (u mlrd \$) & 296,3 & 416,6 & 590,2 & 521,7 & 639,0 & 649,7 \\
\hline 5. & $\begin{array}{l}\text { Vanjskotrgovinska bilanca } \\
\text { (u mlrd \$) (3-4) }\end{array}$ & 9,4 & 0,1 & $-45,9$ & $-50,7$ & $-56,6$ & $-52,6$ \\
\hline 6. & $\begin{array}{l}\text { Vrijednost izvoza roba i usluga } \\
\text { (u mlrd \$) }\end{array}$ & 411,3 & 560,0 & 740,1 & 668,1 & 825,5 & 862,8 \\
\hline 7. & $\begin{array}{l}\text { Vrijednost uvoza roba i usluga } \\
\text { (u mlrd \$) }\end{array}$ & 381,7 & 538,6 & 759,1 & 689,4 & 854,5 & 889,4 \\
\hline 8. & Platna bilanca (6-7) & 29,6 & 21,4 & $-19,0$ & $-21,3$ & $-29,0$ & $-26,6$ \\
\hline 9. & Godišnja stopa inflacije (\%) & 1,9 & 2,1 & 1,5 & 0,1 & 0,9 & 1,1
\end{tabular}

Izvor: rad autora, korišteni podaci The World Bank, preuzeto s: https://databank.worldbank.org/ reports.aspx?source=world-development-indicators $(22.7 .2021$.)

Danas je francusko gospodarstvo peto po veličini na svijetu i ostvaruje oko petinu BDP-a zemalja europodručja. Inflacija je u godini koja je prethodila uvođenju eura iznosila 1,6 \%. Godine 2002. inflacija je iznosila $1,9 \%$, a 2019. godine $1,1 \%$. 


\subsubsection{Slovenija}

Slovenija je članica EU-a od 2004. godine i prva je tranzicijska država koja je 2007. godine, uvođenjem eura kao nacionalne valute, postala članicom EMU-a. Te godine, stopa inflacije iznosila je 3,66 \% dok je u 2019. godini, stopa inflacije iznosila 1,63 \%. U Tablici 5. prikazani su makroekonomski pokazatelji Slovenije u promatranom razdoblju koji potvrđuju pozitivne trendove kretanja BDP-a, BDP-a po glavi stanovnika, vanjskotrgovinske bilance i platne bilance. Ulaskom u EMU, u Sloveniji je zabilježen najveći porast cijena u uslužnim sektorima: restoranima, kafićima, rekreativnim i sportskim ustanovama, prijevoznom sektoru, a povećane su i cijene za popravak obuće i popravak kućanskih aparata. (Pufnik, 2017, prema Širanović, 2021).

Tablica 5. Makroekonomski pokazatelji Slovenije 2002. - 2019. godine

\begin{tabular}{c|l|c|c|c|c|c|c} 
R.B. & Makroekonomski pokazatelji & $\mathbf{2 0 0 2 .}$ & $\mathbf{2 0 0 4 .}$ & $\mathbf{2 0 0 7 .}$ & $\mathbf{2 0 0 9 .}$ & $\mathbf{2 0 1 3 .}$ & $\mathbf{2 0 1 9 .}$ \\
\hline 1. & BDP (u mlrd \$) & 23,5 & 34,4 & 48,0 & 50,4 & 48,4 & 54,2 \\
\hline 2. & BDP po glavi stanovnika (u \$) & 11.777 & 17.233 & 23.788 & 24.694 & 23.497 & 25.941 \\
\hline 3. & Izvoz robe (u mlrd \$) & 10,4 & 16,0 & 27,6 & 22,7 & 28,8 & 35,8 \\
\hline 4. & Uvoz robe (u mlrd \$) & 10,7 & 17,2 & 29,3 & 23,3 & 27,8 & 34,4 \\
\hline 5. & $\begin{array}{l}\text { Vanjskotrgovinska bilanca } \\
\text { (u mlrd \$) (3-4) }\end{array}$ & $-0,3$ & $-1,2$ & $-1,7$ & $-0,6$ & 1,0 & 1,4 \\
\hline 6. & $\begin{array}{l}\text { Vrijednost izvoza roba i usluga } \\
\text { (u mlrd \$) }\end{array}$ & 12,3 & 18,9 & 32,6 & 28,8 & 35,9 & 45,4 \\
\hline 7. & $\begin{array}{l}\text { Vrijednost uvoza roba i usluga } \\
\text { (u mlrd \$) }\end{array}$ & 12,1 & 19,4 & 33,2 & 28,1 & 33,7 & 40,8 \\
\hline 8. & Platna bilanca (6-7) & 0,2 & $-0,5$ & $-0,6$ & 0,7 & 2,2 & 4,6 \\
\hline 9. & Godišnja stopa inflacije (\%) & 7,5 & 3,6 & 3,7 & 0,8 & 1,8 & 1,6
\end{tabular}

Izvor: rad autora, korišteni podaci The World Bank, preuzeto s: https://databank.worldbank.org/ reports.aspx?source=world-development-indicators $(22.7 .2021$.

\subsection{Tijek operacionalizacije zamjene kune eurom}

Vlada Republike Hrvatske i Hrvatska narodna banka (HNB) predviđaju da će 1. siječnja 2023. euro postati zakonsko sredstvo plaćanja u Hrvatskoj. Radi toga su zajedno izradili strateški dokument pod nazivom Nacionalni plan zamjene hrvatske kune eurom, u kojem su definirane operativne mjere za odvijanje ovog procesa, odnosno pravila za preračunavanje cijena, konverziju depozita i kredita te kamatnih stopa. Dio pripreme čini i procedura za odabir motiva hrvatske nacionalne strane kovanica eura koje će biti puštene u optjecaj i ravnopravno kolati u svim zemljama europodručja. 


\subsubsection{Kovanice eura s hrvatskom nacionalnom stranom}

Iako u europodručju postoje zemlje koje su odlučile da na nacionalnoj strani svojih kovanica eura imaju osam motiva, druge zemlje su se odlučile za tri motiva, a postoji i primjer zemalja sa samo jednim motivom (Vlada Republike Hrvatske, 2021), Hrvatska se odlučila za pet motiva. Komisija za novac HNB-a pokrenula je proces savjetovanja s javnošću oko odabira predloženih pet motiva koji bi trebali biti na nacionalnoj strani optjecajnog kovanog novca, a to su: šahovnica, geografska karta Hrvatske, kuna, glagoljica i Dubrovnik. U istraživanju je sudjelovalo 50.000 građana koji su pored ocjenjivanja predloženih motiva imali mogućnost predložiti i neki drugi motiv. Oko 11.000 građana iskoristilo je tu mogućnost i iznijelo svoje slobodne prijedloge, a čak 2.600 je predložilo lik Nikole Tesle pa je tako umjesto motiva Dubrovnika, Nikola Tesla izabran kao peti motiv.

\section{Slika 2. Predloženi motivi za nacionalnu stranu eurokovanica}
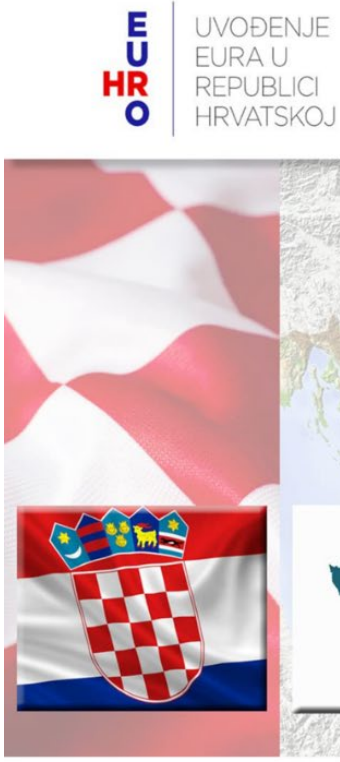

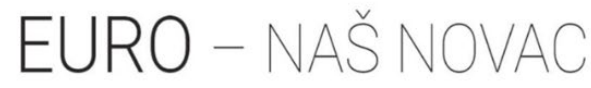

MOTIVI NA NACIONALNOJ STRANI EUROKOVANICA

Izvor: Vlada Republike Hrvatske, preuzeto s: https://vlada.gov.hr/vijesti/sahovnica-geografskakarta-hrvatske-kuna-glagoljica-i-nikola-tesla-predlozeni-motivi-za-hrvatsku-stranueurokovanica/32596 (21.7.2021.)

Krajem srpnja 2021. godine, utvrđeno je da će šahovnica biti zajednička podloga na svim kovanicama, dok će na dva eura biti karta Hrvatske, a na jednom euru motiv kune. Motiv Nikole Tesle bit će na 50, 20 i 10 centi, a glagoljica na kovanici od pet, dva i jednog centa.

Prema informacijama predstavnika HNB-a (N1, 2021), izrađen je terminski plan tijeka procesa uvođenja eura u Republiku Hrvatsku što je vidljivo na Slici 3. 


\section{Slika 3. Tijek operativnih aktivnosti uvođenja eura u Republiku Hrvatsku od rujna} 2021.-prosinca 2022.
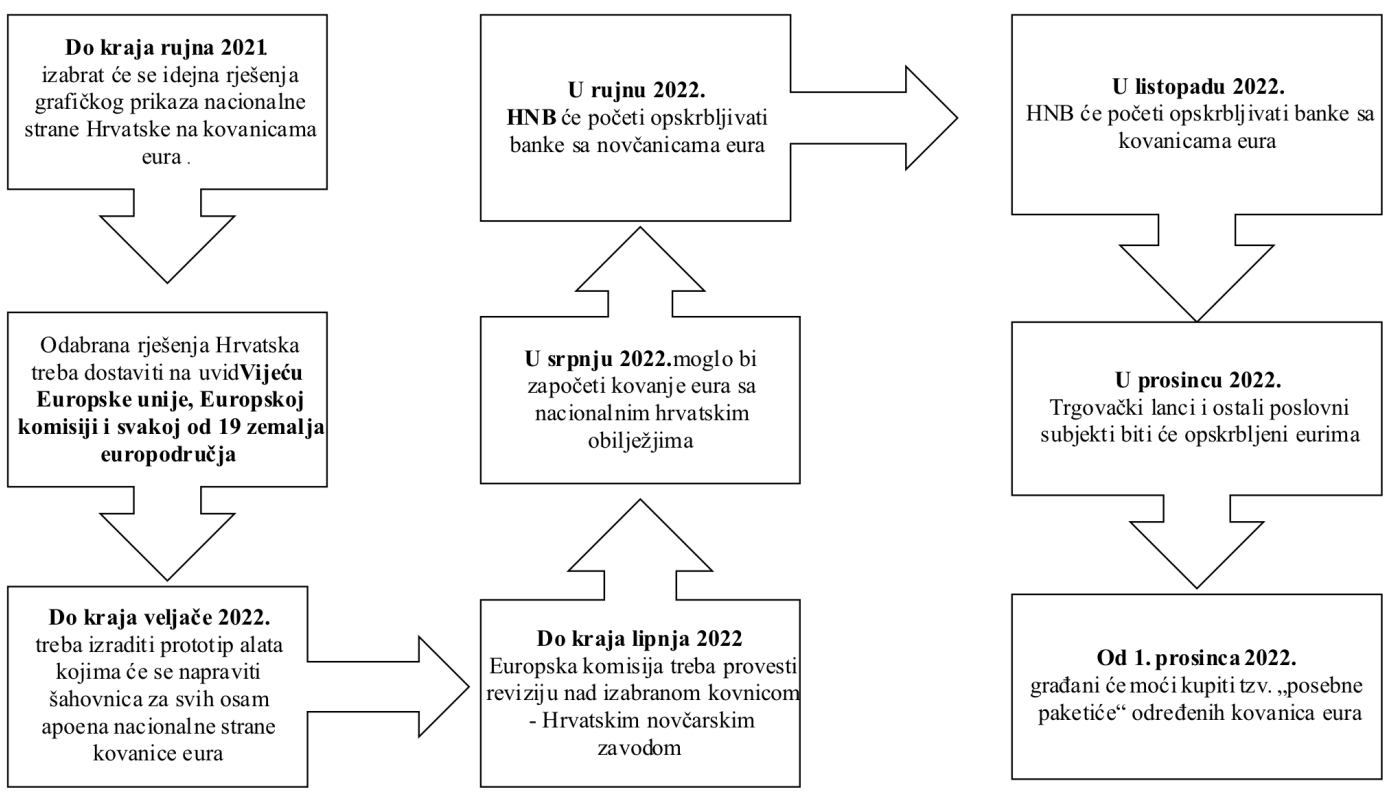

Izvor: rad autora, prilagođeno, preuzeto s: https://www.youtube.com/watch?v=tEA8rGJE4j0 (29.7.2021.)

Rezultati provedenog javnog natječaja za prikupljanje idejnih rješenja grafičkog prikaza hrvatske nacionalne strane na eurokovanicama bit će poznati do kraja rujna 2021., nakon čega će se dostaviti na uvid Vijeću Europske unije, Europskoj komisiji i svakoj od 19 zemalja europodručja koji mogu u roku od sedam dana dostaviti svoje primjedbe. Do kraja veljače 2022. godine treba izraditi prototip alata za sve apoene nacionalne strane kovanice eura, a do kraja lipnja 2022. Europska komisija treba provesti reviziju da bi dobila uvid zadovoljava li Hrvatski novčarski zavod, kao izabrana i provjerena kovnica, potrebne tehničke preduvjete za kovanje eura pa bi u srpnju 2022. moglo započeti kovanje eura s nacionalnim hrvatskim obilježjima. HNB će četiri mjeseca prije uvođenja eura početi opskrbljivati banke novčanicama, a najranije tri mjeseca prije uvođenja eura kovanicama kako bi banke, počevši od dana uvođenja eura, mogle građanima i poduzećima pružati uslugu zamjene valute u potrebnom obujmu. Trgovački lanci i ostali poslovni subjekti bit će opskrbljeni eurima mjesec dana prije datuma uvođenja eura kako bi od dana uvođenja eura kupcima mogli vraćati isključivo eure. Za građane će biti osigurani tzv. „posebni paketići“ određenih kovanica eura koje će biti moguće kupiti već 1. prosinca 2022., dakle mjesec dana ranije prije datuma zamjene hrvatske kune eurom. 


\subsubsection{Preračunavanje kuna u eure i troškovi ovih aktivnosti}

Preračunavanje kuna u eure, koje se nalaze na računima građana i tvrtki u domaćim bankama, provest će banke na dan uvođenja eura prema fiksnom tečaju konverzije (očekuje se da to bude 1 EUR $=7,53450 \mathrm{kn}$ ), tako što će izvršiti preračunavanje i zatim zaokružiti dobiveni iznos na dvije decimale. Ovo preračunavanje banke će obaviti bez naknade. Kunski krediti s valutnom klauzulom u eurima bit će preračunati u eure s obvezom da se financijsko stanje dužnika ne pogorša. Kod kredita koji imaju utvrđenu fiksnu kamatnu stopu, ona kao takva ostaje nepromijenjena, a kod kredita $s$ promjenjivom kamatnom stopom, promjene ugovora o kreditu snosit će banke, a te promjene ne smiju pogoršati financijski položaj dužnika (EURO HNB, 2021).

U državama europodručja, troškovi uvođenja eura iznosili su prosječno 0,5 \% BDP-a, što bi značilo da bi Hrvatska mogla imati troškove vezane uz potrebne tehničke radnje i prilagodbe kao što je postupak uništavanja novčanica i kovanica kuna, troškovi kovanja eurokovanica, prilagođavanje bankomata za eure, prilagođavanje softvera na POS uređajima i drugo u iznosu i do 1,85 milijardi kuna. Guverner HNB, Boris Vujčić ilustrirao je zamjenu kuna eurom na sljedeći način:

„Ta kompleksna operacija mora osigurati brz i praktičan prelazak na euro u svim dijelovima zemlje. O zahtjevnosti pothvata najbolje govori činjenica da će trebati povući više od 500 milijuna komada novčanica kuna, koje bi položene jedna na drugu formirale 50-kilometarski stup, dakle gotovo šest visina Mount Everesta, te više od 1,1 milijarde komada kovanica kuna i lipa, koje ukupno teže kao 120 zagrebačkih električnih tramvaja, a prostor nogometnog igrališta ispunile bi do visine od pola metra." (Vlada RH i HNB, 2020). 


\section{Zaključak}

U radu je naglašeno da zamjena hrvatske kune eurom predstavlja vrlo važan povijesni, politički i gospodarski događaj koji zahtijeva detaljnu pripremu i provođenje procesa operacionalizacije složenih monetarnih i fiskalnih aktivnosti. Rezultati provedene analize potvrđuju da postoji realna mogućnost za ostvarivanje tri zadana Kriterija nominalne konvergencije, a to su: stabilnost cijena, stabilnost tečaja i stabilnost dugoročnih kamatnih stopa. Prosječna dvanaestomjesečna stopa inflacije u Hrvatskoj od 0,9 \% niža je od referentne stope inflacije koja je u promatranom razdoblju iznosila $1,8 \%$. Također, Hrvatska bilježi vrlo blagu fluktuaciju tečaja hrvatske kune prema euru (od 7,3571 do $7,4868)$ čime potvrđuje stabilnost tečaja, a ostvaruje i relativno nisku kamatnu stopu na dugoročne državne obveznice $(0,9 \%)$ u odnosu na referentnu stopu koja je u promatranom razdoblju iznosila 2,9 \%. Međutim, ostvarivanje Kriterija održivosti javnih financija traži puno složeniji odgovor s obzirom na to da proračunski deficit treba biti manji od $3 \%$, a 2020. godine zabilježen je proračunski deficit od 7,4 \%. Također, udio javnog duga u BDP-u treba biti manje od $60 \%$, a u 2020. godini Hrvatska je imala $88,7 \%$. Ako se ostvare poslovna očekivanja predstavnika hrvatske izvršne i monetarne vlasti da će u nadolazećim godinama prosječno smanjenje udjela javnog duga u BDP-u biti 3,3 \% godišnje i da će se intenzivirati gospodarska aktivnost pa time i proračunski deficit smanjiti na ispod $3 \%$, BDP-a, i Kriterij održivosti javnih financija bit će ostvaren.

Iskustva drugih zemalja članica europodručja potvrđuju da će uvođenje eura dovesti do vrlo blage inflacije od samo 0,20 postotnih bodova u odnosu na povećanje indeksa potrošačkih cijena. Znatnije bi mogle porasti cijene proizvoda i usluga vezane uz ugostiteljstvo, smještaj, sportske, rekreativne i kulturne sadržaje, frizerske i kozmetičke usluge te cijene proizvoda koje konzumiraju građani s višim dohotkom. Iskustva država europodručja pokazuju značaj da su cijene u trgovinama, što je moguće duže razdoblje, istaknute u obje valute. Zamjena kune eurom imat će izravan utjecaj na hrvatske gospodarstvenike i na građane, ali to ne znači da će utjecaj biti ravnomjeran u svim sektorima, skupinama stanovništva ili za sve građane. U potpunosti će nestati valutna klauzula koja je sada prisutna u više od $90 \%$ ukupnih deviznih kredita, više neće biti dosadašnjih troškova konverzije koji su postojali zbog razlike u kupovnom i prodajnom tečaju, kao niti obveze plaćanja naknada i provizija bankama i mjenjačnicama. Pored toga, građani mogu očekivati niz novih pogodnosti u svakodnevnom životu koje se odnose na transparentnost cijena, smanjenje kamatnih stopa, korištenje iste valute prilikom putovanja u države članice europodručja. Za gospodarstvenike će biti olakšana međunarodna razmjena s državama članicama europodručja, pa se očekuje i povećanje izvoza, a zbog povoljnijih uvjeta kreditiranja može se očekivati jačanje poslovne i investicijske gospodarske aktivnosti te poticanje stranih ulaganja. Također, za očekivati je i povećani dolazak turista u Hrvatsku iz država europodručja. Za Republiku Hrvatsku očekuje se povećanje kreditnog rejtinga, povećanje mogućnosti financiranja na tržištima kapitala te, kao države članice europodručja, brži gospodarski rast i razvoj. Preporuka za buduća istraživanja sastoji se u potrebi kontinuiranog praćenja trenda kretanja smanjenja proračunskog deficita i udjela javnog duga u bruto društvenom proizvodu Republike Hrvatske. 


\section{Literatura}

Čuić, M. (2016). Značaj i ograničenja kriterija nominalne konvergencije [Diplomski rad, Sveučilište u Splitu, Ekonomski fakultet] Repozitorij Ekonomskog fakulteta u Splitu.

https://repozitorij.efst.unist.hr/islandora/object/efst\%3A46/datastream/PDF/view.

Državni zavod za statistiku (2021). Izvješće o proceduri prekomjernoga proračunskog manjka i razini duga opće države, Republika Hrvatska, travanj 2010. (ESA 2010), priopćenje br. 12.1.2/1, godina LVIII, 1. https://www.dzs.hr/Hrv Eng/publication/2021/12-01-02 01 2021.htm.

Erstebank (2021). Informacije o valutnoj klauzuli i kretanju tečaja EUR-a, https://www.erstebank.hr/hr/ gradjanstvo/krediti/informacije-o-valutnoj-klauzuli-i-kretanju-tecaja-eura.

Eurostat newsrelease euroindicators (2019). Annual inflation up to 1.3\% in the euro area: Stable at $1.6 \%$ in the EU, https://ec.europa.eu/eurostat/documents/portlet file entry/2995521/2-17072019AP-EN.pdf/e507c971-54f9-4c0f-96d6-d619a8a912aa.

Europska središnja banka - Eurosustav (2020). Izvješće o konvergenciji ESB-a, lipanj 2020., https://www.ecb.europa.eu/pub/convergence/html/ecb.cr202006 9fefc8d4c0.hr.html.

Europska središnja banka - Eurosustav (2021). Euro, Austrija, https://www.ecb.europa.eu/euro/ exchange/au/html/index.hr.html.

Europa EU (2021). Europska unija - O Europskoj uniji - Hrvatska. https://europa.eu/european-union/ about-eu/countries/member-countries/croatia hr.

Frank, B. i Bernanke, B. (2001). Principles of Economics. McGraw-Hill Higher Education.

HNB (2021). Raste podrška uvođenju eura - rezultat anketnog ispitivanja hrvatskih građana u veljači 2021., phttps://www.hnb.hr/-/raste-podrska-uvodjenju-eura-rezultat-anketnog-ispitivanjahrvatskih-gradjana-u-veljaci-2021.

Hrvatska turistička zajednica (2021). Informacija o statističkim pokazateljima turističkog prometa siječanj-srpanj 2021., https://www.htz.hr/sites/default/files/2021-08/Informacija\%20o\%20 statistickim\%20pokazateljima\%20-\%20srpanj\%202021 0.pdf.

Ministarstvo turizma Republike Hrvatske (2020). Turizam u brojkama 2019. https://www.htz.hr/ sites/default/files/2020-07/HTZ\%20TUB\%20HR \%202019\%20\%281\%29.pdf.

N1 (2021.) Tihomir Mavriček: Kovanice kune će se moći mijenjati 3 godine, novčanice neograničeno, https://www.youtube.com/watch?v=tEA8rGJE4j0.

Reinhart C, Rogoff K. (2009). Ovaj put je drukčije. Osam stoljeća financijske gluposti.

Hrvatska gospodarska komora.

Šarganović, H. (2020). Analiza nominalnih kriterija konvergencije za uvođenje eura u Hrvatskoj, stanje i perspektive pred sljedeći Izvještaj o konvergenciji Europske komisije i Europske centralne banke 2020. godine, https://www.ceps.edu.ba/Files/DIT/Godina\%206\%20Broj\%201/19.pdf?.ver=1. 
Širanović P., (2021). Očekivani utjecaji uvođenja eura na gospodarska kretanja u Republici Hrvatskoj [Završni rad. Sveučilište VERN'].

The World Bank (2021). DataBank - World Development Indicators, https://databank.worldbank.org/reports.aspx?source=world-development-indicators.

Trading Economics (2021). Croatia Government Budget, https://tradingeconomics.com/croatia/ government-budget.

Trading Economic (2021). Croatia Government Debt to GDP, https://tradingeconomics.com/ croatia/government-debt-to-gdp.

Vlada Republike Hrvatske, https://vlada.gov.hr/vijesti/sahovnica-geografska-karta-hrvatske-kunaglagoljica-i-nikola-tesla-predlozeni-motivi-za-hrvatsku-stranu-eurokovanica/32596.

Vlada Republike Hrvatske (2020). Ulazak Hrvatske u europodručje mogao bi biti riješen do kraja mandata iduće Vlade, https://vlada.gov.hr/vijesti/ulazak-hrvatske-u-europodrucje-mogao-bi-bitirijesen-do-kraja-mandata-iduce-vlade/29938.

Vlada Republike Hrvatske (2021). Nacionalna strana kovanica eura Republike Hrvatske. Hrvatska narodna banka, https://vlada.gov.hr/UserDocsImages/Vijesti/2021/srpanj/Odabir\%20hrvatske\%20 nacionalne $\% 20$ strane $\% 20$ eurokovanica.pdf.

Vlada Republike Hrvatske i Hrvatska narodna banka (2020) Nacionalni plan zamjene hrvatske kune eurom, https://euro.hnb.hr/documents/2070751/2104255/Nacionalni-plan-zamjene-hrvatsk-kune-eurom prosinac-2020.pdf/6bcd2d43-5ef8-1a8d-00d1-86b9a71c696f. 


\title{
Replacement process of Croatian Kuna with Euro and expected impact on economic developments
}

\author{
VESNA CVITANOVIĆ \\ VERN' University, Zagreb \\ PETRA ŠIRANOVIĆ \\ Croatian National Bank
}

\begin{abstract}
This paper presents the research on the operationalization flow of the replacement process of the Croatian kuna with the euro. Realistic possibilities for Croatia to fulfill the mandatory criteria of nominal convergence are identified. The aim of this paper is to confirm the hypothesis that adoption of euro will have a positive impact on the standard of living of Croatian citizens, on the business of companies and on macroeconomic indicators. In the research, secondary sources were used as well as official publications, online sources, and in generating of research conclusions, the methods of comparison, synthesis, and induction were used. Research results include the following conclusions: a realistic possibility that Croatia will fulfill all criteria of nominal convergence and subsequently join the euro area in 2023. The advantages which adoption of the euro will bring to Croatia include: a slight growth of prices, elimination of currency risk, reduction of cost of borrowing, stimulation of international exchange and foreign investment, and faster economic growth.
\end{abstract}

Keywords: euro, European Union, euro area, CNB, economy 